\title{
Reproduction and recruitment of the barnacle Chthamalus montagui at Aberystwyth (mid-Wales)
}

\author{
Michael A. Kendall \& Marianne L. Bedford \\ NERC Rocky Shore Surveillance Group, University of Newcastle on Tyne, Dove Marine Laboratory, Cullercoats, North Shields, Tyne \& Wear \\ NE30 4PZ, United Kingdom
}

\begin{abstract}
Data on the recruitment of Chthamalus montagui were collected over the 7 yr period 1979-85 at a site in Wales close to the species northern geographic limit. When compared with data from more southerly sites they show that the breeding period, the period of larval settlement, and the density of recruits are all reduced in the northern part of the species range. Intensive studies of settlement carried out during 1985 confirmed that poor recruitment was a result of low numbers of cyprids reaching the shore. Such poor larval supply occurs annualy; it is therefore proposed that competition with Semibalanus balanoides, which Connell (1961) suggested sets the northern limit od C. montaqui, can only act to intensify the effects of a restricted breeding period and the consequential low level of larval recruitment.
\end{abstract}

The range of the barnacle Chthamalus montagui (Southward 1976) extends from the north of Scotland to the Mediterranean Sea (Crisp et al. 1981). On the shores of the Firth of Clyde, Scotland, towards the species' northern limit of distribution, competition with the boreal Semibalanus balanoides (L.) limits C. montagui to a relatively narrow band at the top of the shore from which the former is excluded by its intolerance to desiccation (Connell 1961, Foster 1971). It has been suggested that as summer conditions become less severe further to the north, the boundary between the 2 species should move upshore and eventually reach a level where C. montagui is totally displaced. On the east coast of the USA, Wethey (1983) has demonstrated a similar relationship between $S$. balanoides and Chthamalus fragilis and suggested that the northern limit of the latter is set by competition.

In view of both the unusually high levels of Semibalanus balanoides settlement in Connell's study area (Kendall et al. 1982), and the latitudinal variation in the breeding cycle of other barnacles (Hines 1978), it would be unwise to restrict discussion of the factors setting the geographic limits of Chthamalus montagui to competition alone. Hines (1978) discussed the way in which a number of barnacles with wide distributions have a restricted breeding period in the northern part of their range. For example, in central and southerm California Pollicipes polymerus reproduces throughout the year but in more northerly populations breeding is restricted to summer (Hines 1978). No comparable field data for $C$. montagui exist although Patel \& Crisp (1960) have shown in the laboratory that 'C. stellatus' (probably C. montagui) will breed only at temperatures above $15^{\circ} \mathrm{C}$. This would suggest that the extent of its breeding season should vary latitudinally, becoming progressively shorter with distance north.

In an intensive study of Semibalanus balanoides (Kendall et al. 1985) it has been shown that annual variability in the density of recruitment is the result of differences in the cyprid supply to the shore. In such cases, factors acting after larval settlement could only serve to modify the final total of spat. The possibility that the low annual recruitment of Chthamalus montagui to sites close to its northern limit could, similarly, be the result of a poor supply of larvae was therefore investigated during the summer of 1985.

The population of Chthamalus montagui studied (at Aberystwyth) appears to be typical of many others close to the species' northern limit. Although annual reruitment is low (see below), as a result of the species' increased longevity in the north (Lewis 1964) the rock surface within the zone it occupies is generally totally covered.

Methods. The study was carried out on a small jetty of hard igneous rock situated about $200 \mathrm{~m}$ to the north of the promenade at Aberystwyth, Dyfed, mid-Wales $\left(52^{\circ} 25^{\prime} \mathrm{N}, 4^{\circ} 05^{\prime} \mathrm{W}\right)$. In June of each year from 1979 to 1985,3 areas of $250 \mathrm{~cm}^{2}$ on each side of the jetty were cleared of all flora and fauna; the uppermost of these sites was positioned close to the highest surviving Chthamalus montagui and the lowest at the overlap between that species and Semibalanus balanoides, a 


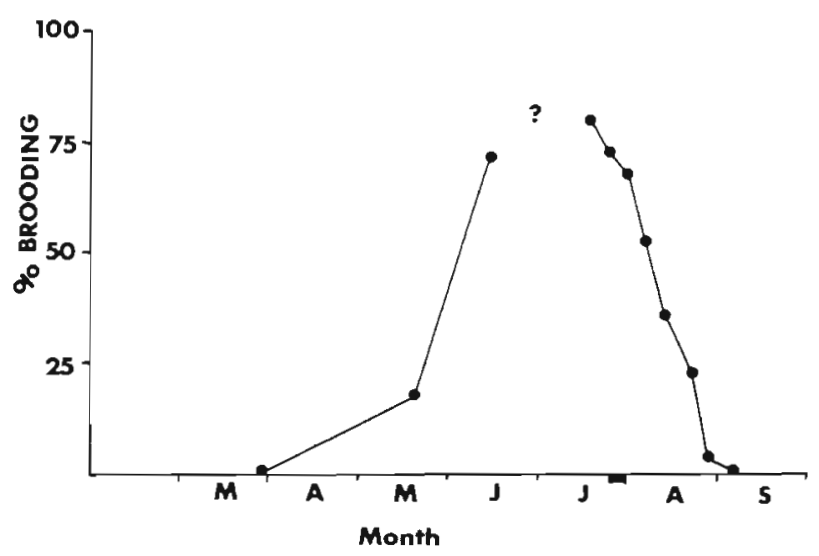

Fig. 1. Chthamalus montagui. Proportion of adults at a midzone site brooding nauplii during 1985. Horizontal bar denotes the onset of spat settlement
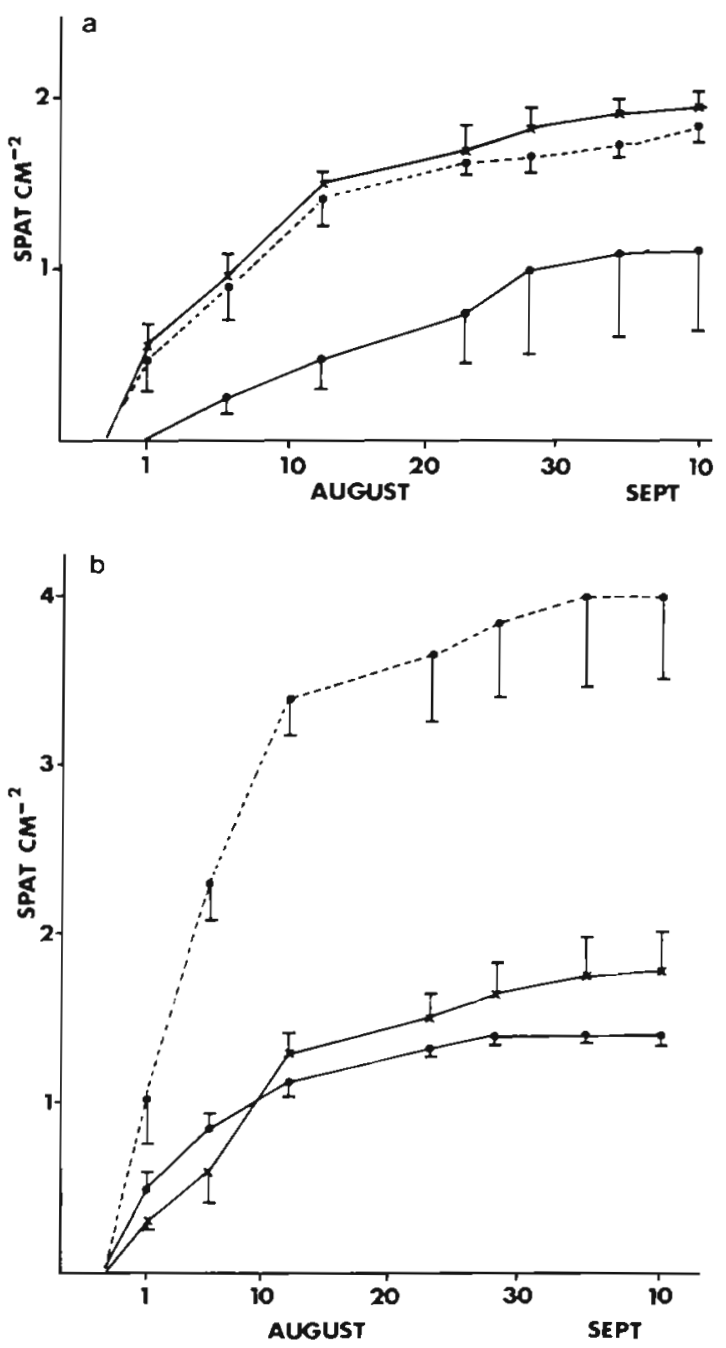

Fig. 2. Accumulation of spat (mean of 3 replicates and one standard deviation) at 3 levels within the Chthamalus montagui zone, summer 1985. (a) Northerly aspect; (b) southerly aspect. $(\bullet-)$ upper; $(\mathrm{x}-\mathrm{x})$ mid; $(\bullet . .-\bullet)$ lower vertical separation of about $2 \mathrm{~m}$. A third site was established in the mid-zone. Sites on the south side of the jetty were at an equivalent height to those on the north side. In late September or early October the number of C. montagui spat on each site was counted to provide an annual estimate of the density of recruits.

In 1985, a further 3 sites, each of $50 \mathrm{~cm}^{2}$ were set up at each level on each side of the jetty. These were examined at intervals of between 7 and $10 \mathrm{~d}$ throughout the settlement period. On each occasion the position of all spat was recorded on a transparent acetate overlay. In this way a record of the temporal pattern of their accumulation could be developed and estimates of their rate of mortality established.

In 1985, studies of settlement were complemented by regular examination of 100 adult barnacles in order to establish the proportion of the population brooding nauplii and hence the timing and extent of the breeding season. In earlier years sampling was performed less frequently. Such sampling is necessarily destructive and hence it is not possible to assess the number of broods produced annually.

Results. Data collected prior to 1985 show that brooding generally begins during late May or early June and continues until late August, although there are no records of more than $90 \%$ of the adult population in

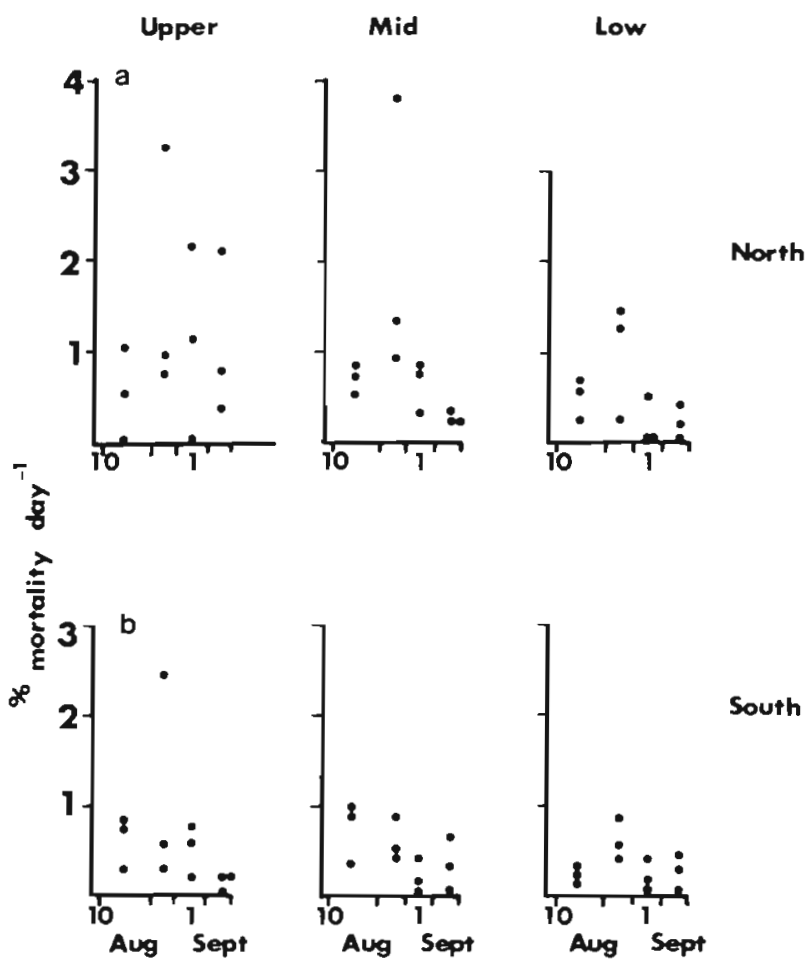

Fig. 3. Chthamalus montagui. Mortality of newly settled spat on 3 replicate sites at each of 3 zone levels having either (a) a northerly aspect or (b) a southerly aspect. Each point represents an estimate of daily mortality in the period marked on the $x$-axis 
this condition at any one time. Cyprid larvae begin to settle during the second or third week of July and continue to do so throughout August and into early September.

In 1985, preliminary sampling showed that there was a rapid rise in the proportion of individuals brooding between mid-May and mid-June. When more regular studies began on $18 \mathrm{Jul} 1985,80 \%$ of the population contained nauplii and hence it is possible that the initial phase of release may have been missed. Over the following $6 \mathrm{wk}$ the proportion of the population brooding nauplii declined slowly until the end of August (Fig. 1); during this period the inshore sea temperature varied between 15.3 and $18.8^{\circ} \mathrm{C}$.

In 1985 , cyprid settlement began between 29 Jul and 1 Aug and was effectively finished by the end of the month (Fig. 2). By that time, the small number of cyprids settling only just compensated for spat mortality. The settlement rate was greatest during the first $2 \mathrm{wk}$, as by 12 Aug (considering all the sites together) $70 \%$ ( $\pm 14.5 \mathrm{SD}$ ) of the final total of spat had settled. Within the cleared area cyprids attached preferentially in grooves and pits. Analysis of variance shows that there was a highly significant interaction between the effects of tidal height and aspect on the number of cyprids becoming established on any particular site, density being greatest at the lowest level on the south side of the jetty and least at high level on the north side (Fig. 2).

From records of the position of individual metamorphs it was possible to estimate the daily mortality rate over 4 periods of between 5 and $11 \mathrm{~d}$. During periods of this length it is possible for spat to die and be replaced by new individuals which occupy precisely the same spot. While most such instances will be detected some will undoubtedly have been missed and hence some of the mortality estimates may be slight underestimates. Nevertheless, over the whole settlement period the mean daily mortality of spat was low (3.5\% $\pm 1.75 \mathrm{SD})$. Mortality was greatest between 20 and 30 Aug (Fig. 3) and did not vary significantly with tidal height or aspect (analysis of variance on arcsine transformed data). This suggests that the observed differences in settlement intensity were the direct result of differences in larval supply/selectivity rather than the result of differential mortality.

Over the $7 \mathrm{yr}$ of study, the density of spat at the end of the settlement period varied between near total failure in 1982 and $4.1 \mathrm{~cm}^{-2}$ at the lowest southern site in 1985. It is clear from Fig. 4 that recruitment was best in 1985 and 1984 but even in these 'good' years numbers were low, only exceeding 2 spat $\mathrm{cm}^{-2}$ on one site on a single occasion. No significant correlation between summer air temperatures and spat numbers could be established.

There was a consistent pattern of settlement on the southern side of the jetty where in 6 of the 7 yr studied spat were most dense at the lowest and least dense at the highest sites. This pattern occurred only once on the northern side.

Discussion. If the breeding period of Chthamalus montagui at Aberystwyth is compared with that in N Spain, towards the centre of the species range (Myares 1986), there are a number of substantial differences. At Aberystwyth brooding is generally first observed during May and by the end of June or the start of July in excess of $80 \%$ of the population contains a naupliar mass. The proportion in this state then declines slowly until the end of August. Cyprid settlement begins in late July and is effectively over by early September. Similarly short settlement periods have been regularly observed in $\mathrm{N}$ Scotland over the past

Fig. 4. Chthamalus montagui. Annual variation in the abundance of spat on 3 sites at different levels on each side of the Aberystwyth jetty. Based on total counts of areas of approximately $250 \mathrm{~cm}^{2}$ made at the end of the settlement season
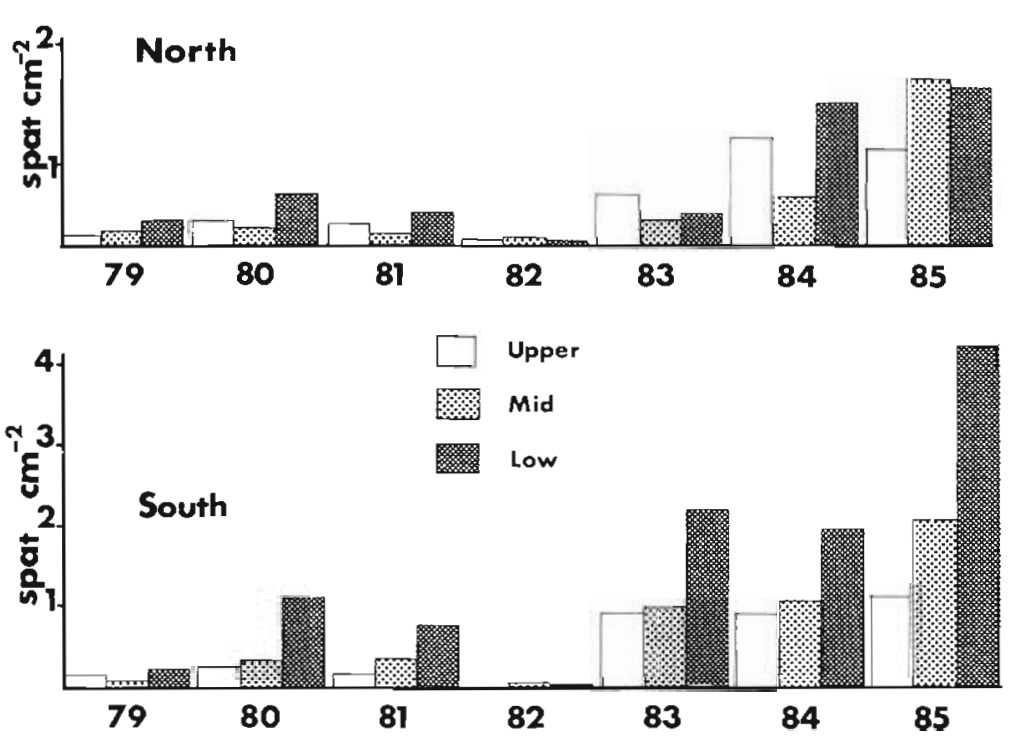
15 yr (R. S. Bowman unpubl.). In N Spain, brooding begins in April and extends until early October although at any given time, no more than about $30 \%$ of the population contain nauplii. Larval settlement occurs from the end of May until October and sometimes November (Myares 1986). In addition to these differences in timing there are also considerable differences in the success of recruitment. The heaviest spat settlement recorded in the $7 \mathrm{yr}$ study at Aberystwyth gave a density of 4 spat $\mathrm{cm}^{-2}$ but in other years numbers were substantially lower. In NW Spain numbers may be much higher, as Myares (1986) has recorded up to 20 spat $\mathrm{cm}^{-2}$. Thus, in the centre of the species range the breeding period is longer and settlement densities are greater than at Aberystwyth. This trend can also be seen when data from SW England are considered; Burrows (pers. comm.) has shown that at Plymouth brooding continues from mid-April to mid-September while settlement occurs from mid-July to early October.

The reproductive strategy adopted by Chthamalus montagui, the production of numerous small broods in rapid succession throughout the summer (Patel \& Crisp $1960)$, could be seen as maximising the probability of reproductive success in an environment liable to shortterm variation (Hines 1978). In the laboratory, brooding only occurs at temperatures above $15^{\circ} \mathrm{C}$ (Patel \& Crisp 1960) and hence this strategy would be most effective in a warm temperate or tropical environment where many batches of larvae can be produced and where the chances of one or more of them encountering favourable planktonic conditions will be high. At cooler, more northerly, latitudes a shorter breeding period, and as a consequence a smaller number of broods, will substantially decrease the chances of a successful larval settlement. In the Aberystwyth study we have shown that the low numbers of metamorphs at the end of the season result from poor cyprid settlement, rather than high post-settlement mortality.

Variation in the intensity of cyprid settlement has been shown to account for both spatial (Caffey 1985, Kendall et al. 1985) and temporal (Kendall et al. 1985) variation in barnacle recruitment. Although there are many other processes which can lead to mortality among settled spat, and hence affect recruitment to the breeding population, these could only influence those cyprids which manage to reach the shore and metamorphose. Thus, the competition between Chthamalus montagui and Semibalanus balanoides which was observed by Connell (1961) could only act to set the species' northern limit by intensifying the effects of poor larval settlement.

Acknowledgements. The work described in this paper was part of the programme of the NERC Rocky Shore Surveillance Group and is a U.K. contribution to the COST 647 programme of the Commission of the European Communities. The original Aberystwyth study sites were set up by Dr Phillip Williamson and the work has benefited greatly from the comments and encouragement of Dr J.R. Lewis; our thanks are due to both. We also acknowledge the assistance of Drs John and Susan Fish who provided facilities at University College Aberystwyth and Drs P. R. Garwood, R. S. Bowman and M. Burrows who commented on the manuscript.

\section{LITERATURE CITED}

Connell, J. (1961). Effects of competition, predation by Thais lapillus and other factors on natural populations of the barnacle Balanus balanoides. Ecol. Monogr. 31: 61-104

Caffey, H. M. (1985). Spatial and temporal variation in settlement and recruitment of intertidal barnacles. Ecol. Monogr. 55: 313-332

Crisp, D. J., Southward, A. J., Southward, E. C. (1981). On the distribution of the intertidal barnacles Chthamalus stellatus, Chthamalus montaqui and Euraphia depressa. J. mar. biol. Ass. U.K. 61: 359-380

Foster, B. A. (1971). Desiccation as a factor in the intertidal zonation of barnacles. Mar. Biol. 8: 12-29

Hines, A. H. (1978). Reproduction in three species of intertidal barnacles from central California. Biol. Bull. mar. biol. Lab., Woods Hole 154: 262-281

Kendall, M. A., Bowman, R. S., Williamson, P., Lewis, J. R. (1982). Settlement patterns density and stability in the barnacle Balanus balanoides. Neth. J. Sea Res. 16 119-126

Kendall, M. A., Bowman, R. S., Williamson, P., Lewis, J. R. (1985). Annual variation in the recruitment of Semibalanus balanoides on the Yorkshire coast 1969-1981. J mar. biol. Ass. U.K. 65: 1009-1030

Lewis, J. R. (1964). The ecology of rocky shores. Hodder \& Stoughton, London

Myares, M. P. (1986). Estudio del horizonte de ChthamalusPatella en el litoral Asturiano. Doctoral thesis, Univ. of Oviedo

Patel, B., Crisp, D. J. (1960). The influence of temperature on breeding and moulting activities of some warm water species of operculate bamacles. J. mar. biol. Ass. U.K. 39: $667-680$

Southward, A. J. (1976). On the taxonomic status and distribution of Chthamalus stellatus (Cirripedia) in the north-east Atlantic region; with a key to the common intertidal barnacles of Britain. J. mar. biol. Ass. U.K. 56: 1007-1028

Wethey, D. S. (1983). Geographic limits and local zonation: the barnacles Semibalanus (Balanus) and Chthamalus in New England. Biol. Bull. mar biol. Lab., Woods Hole 165: $330-341$. 